\title{
O papel do corpo no pensamento ético de Schopenhauer
}

\author{
The role of the body in Schopenhauer's ethical thought
}

\author{
Marinella Morgana Mendonça'
}

Resumo: O presente artigo tem por objetivo demonstrar a participação fundamental do corpo na ética de Schopenhauer. Tomando-se como ponto de partida o mundo como representação, o corpo é a objetidade da Vontade, seu modo mais imediato de se manifestar no mundo. Mas, por outro lado, analisando-se o mundo na perspectiva da Vontade, o corpo é a própria Vontade, experienciada e vivida por meio dos próprios motivos que regem esse objeto desejante. Ao postular a Vontade, una e imperecível, como fundo último da realidade, como faz Schopenhauer, não há como desconsiderar o corpo e o sofrimento humano. E isso não é sem consequências para a ética. Segundo o filósofo, a mesma não reside em boas intenções e nem na busca de algum bem espiritual ou transcendente, mas existe concretamente nas ações efetivas dos indivíduos, que se dirigem aos outros indivíduos, percebidos antes de tudo, como corpos padecentes.

Palavras-chave: Corpo; Ética; Vontade

\begin{abstract}
This paper aims at demonstrating the body's fundamental participation in Schopenhauer's Ethics. When one takes as a starting point the world as representation, the body is the objectivation of the Will, its most immediate way of manifesting itself in the world. But, on the other hand, if one analyzes the world on the Will's perspective, the body is the Will itself, lived and experienced by means of the very own motives that rule this desiring object. By postulating the Will, one and non-perishable, as the ultimate ground of reality - as Schopenhauer does - there is no way to neglect the body and human suffering. And this is not without consequences for Ethics. According to the philosopher, Ethics lies neither in good intentions nor in the search for some spiritual or transcendent good, but it exists concretely in individuals' efective actions, that are driven to other individuals - perceived, before anything else, as suffering bodies.
\end{abstract}

Keywords: Body; Ethics; Will

\section{O papel do corpo no pensamento ético de Schopenhauer}

O objetivo deste artigo é demonstrar o lugar de destaque que o corpo ocupa na ética de Schopenhauer. Diante disso, fez-se um recorte em seu pensamento, abordandose, pois, os apontamentos éticos presentes em O mundo como vontade e como representação (1819) e em Parerga e paralipomena (1851). O texto foi dividido em três partes, em que se pode acompanhar, à medida que o filósofo desenvolve suas ideias acerca da ética, o quão implicado o corpo está neste processo. 


\section{Corpo e ética em O mundo como vontade e como representação}

Nos dezoito parágrafos que constituem o Livro IV de O mundo, Schopenhauer reapresenta o mundo como vontade, a partir de uma segunda consideração: ao alcançar o conhecimento de si, por meio do mundo fenomênico, a Vontade se afirma ou se nega. Tratase, pois, de uma opção da Vontade tomada pela via de conhecimento do todo da vida ${ }^{1}$.

Ao iniciar a sua argumentação, Schopenhauer afirma que o autêntico método para a apreciação filosófica do mundo é o que pergunta pelo "quê", ou seja, aquele que tem por objeto "o ser do mundo sempre igual a si e a aparecer em todas as relações, porém sem se submeter a estas, numa palavra, as Ideias mesmas” (W I, § 53, p. 357). Para ele, também a filosofia, como a arte, emana desse tipo de conhecimento que é, aliás, do qual provém a disposição de espírito, a qual conduz à santidade e à redenção do mundo. Acompanha, então, os caminhos que a Vontade percorre ao longo do conhecimento de si mesma nos seus diferentes graus de objetivação, sendo o homem o mais elevado dos modos de sua objetidade. É, pois, pela entrada em cena no mundo como representação que a Vontade, destituída de conhecimento e, portanto, ímpeto cego e irresistível, atinge o conhecimento de sua volição e do que ela é e quer: nada senão este mundo, a vida, tal como esta existe. O que a Vontade sempre quer é a vida, logo, onde existe Vontade, existirá vida, ou o mundo ${ }^{2}$. Contudo, já que agora se trata de investigar a vida filosoficamente, ou seja, as Ideias, então nascimento e morte não são relevantes, uma vez que se referem apenas ao modo de apresentação das Ideias no mundo. Assim, somente as Ideias têm uma realidade propriamente dita, posto que são a objetidade perfeita da Vontade. Para dar provas disso, o autor discorre sobre como a vida e a morte, assim como a procriação, são fenômenos e, como tal, atualizam-se no presente, que é a forma inseparável e essencial do fenômeno da Vontade: passado e futuro não existiriam sem o presente, que é o ponto que corta o tempo infinitamente em duas direções, permanecendo sempre firme e imóvel. Não faz sentido ao homem, assim, temer a morte como sendo seu aniquilamento, nem tentar se libertar da vida por meio do suicídio, já que a forma da vida é o presente sem fim. Logo, é indiferente à certeza da Vontade de vida como os indivíduos, seus fenômenos, nascem e perecem no tempo.

A natureza, em sua marcha segura e certa, também comprova essa tese. Contra a voz da natureza, sustenta o filósofo, a reflexão pouco pode e, como o homem, em seu íntimo, sabe que é parte dessa natureza, não se atormenta muito com o pensamento da morte inevitável, vivendo como se tivesse de viver para sempre. Quem considera de forma atenta esse modo de pensar do homem terá de reconhecer que o fundamento disso é o fato de a Vontade querer a vida, e que, na verdade, tudo no mundo é somente uma e a mesma coisa: Vontade. Esse é o pensamento único, aqui não diretamente mencionado pelo filósofo, mas sempre subentendido em suas argumentações metafísicas e éticas. Até mesmo um conhecimento filosófico acerca da essência do mundo que não fosse além do que o estamos considerando, ou seja, que não passasse pela experiência da Vontade, sendo, pois, somente reflexivo, poderia ajudar o indivíduo a superar os temores da morte ${ }^{3}$.

O sofrimento faz parte da vida, já que a Vontade não cessa; somente esta certeza pode afastar os tormentos humanos. Munido, pois, do conhecimento do todo da vida, o

Cf. SCHOPENHAUER. O mundo como vontade e como representação. Tomo I. Trad., apresentação, notas e índices Jair Barboza. São Paulo: UNESP, 2005, p. 351, nota de rodapé I. De acordo com o tradutor, a conjunção und, que significa "e", deve, neste caso, ser traduzida por "ou" por não se tratar de uma afirmação seguida de uma negação da vontade. De fato, versa-se sobre uma escolha da vontade, que se afirma ou se nega.

2 Cf. JANAWAY. The Cambridge Companion to Schopenhauer. Cambridge: University Press, 1999, p. 8-11. O autor sugere que a expressão em alemão Wille zum Leben seja traduzida por Vontade de vida em vez de Vontade de viver. Parece que esta versão soa melhor com a ideia de Vontade, apresentada por Schopenhauer, além de ser conveniente para a apreensão que aqui se faz do corpo, e de cada uma de suas partes e funções, como uma expressão dessa mesma Vontade.

Destaque-se, nesse ponto, o papel da razão na metafísica da vontade. Cf. DEBONA. Schopenhauer e as formas da razão: o teórico, o prático e o ético-místico. São Paulo: Annablume, 2010. 
homem percebe a morte com indiferença, como sendo uma falsa aparência ou um mero fantasma sem poder algum diante do que sabe de si:

Ele mesmo é a Vontade, da qual o mundo inteiro é objetivação ou cópia; ele, assim, tem não só uma vida certa, mas também o presente por todo o tempo, presente que é propriamente a forma única do fenômeno da Vontade (W I, § 54, p. 368).

Nesse ponto de seu raciocínio, Schopenhauer faz uma primeira apresentação dos conceitos de afirmação e de negação da Vontade de vida. Ambos serão detidamente abordados por ele no decorrer do Livro IV, mas, desde já, deve-se ressaltar a importância do conhecimento nessas duas ações da Vontade, afirmação e negação, pois, como afirma o filósofo, ambas surgem por meio dele. Contudo, não se trata de um conhecimento abstrato, mas sim de um conhecimento vivido e independente de dogmas, que se exprime exclusivamente pelos atos e condutas e, portanto, por meio do corpo, no qual a Vontade se objetiva, seja se afirmando ou se negando.

Como coisa em si e essência de todo e qualquer fenômeno, a Vontade é livre. O autor insiste nisto ao tratar da liberdade da Vontade ao longo do parágrafo 55 do Livro IV de $O$ mundo e, ainda, no ensaio denominado Sobre a liberdade da vontade (1839) ${ }^{4}$. Os fenômenos estão submetidos ao princípio de razão suficiente em suas quatro formas, quando fundamento e consequência são intercambiáveis nas relações entre o sujeito e o objeto, mas a Vontade não é determinada por nenhum fundamento, logo, não conhece a necessidade. Se a Vontade é livre como coisa em si, nos seus fenômenos individuais, como no agir humano, ela é determinada por motivos aos quais o caráter de cada um reage regular e necessariamente. Vê-se aqui a máxima operari sequitur esse:

Assim como os acontecimentos sempre ocorrem de acordo com o destino, isto é, de acordo com o encadeamento infinito das causas, assim também nossos atos sempre se dão de acordo com o nosso caráter inteligível (W I, $\S 55$, p. 390).

A questão é que é preciso passar pela experiência para se conhecer a si mesmo e aos outros, já que não se tem uma intelecção a priori do caráter inteligível. A possibilidade de felicidade está, então, no autoconhecimento ${ }^{5}$. As ações humanas são apreendidas por meio do que Schopenhauer denomina como caráter empírico, sendo apenas fenômenos dessa Vontade. Afinal, "todas as ações particulares do homem são apenas a exteriorização sempre repetida do seu caráter inteligível, e a indução resultante da soma dessas ações constitui precisamente o seu caráter empírico” (W I, §55, p. 375). Ou, como o próprio filósofo esclarece:

A Vontade não é apenas livre mas até mesmo todo-poderosa. Dela provém não só seu agir, mas também seu mundo. Tal qual ela é, assim aparecerá seu agir assim aparecerá seu mundo: ambos são seu autoconhecimento e nada mais. Ela determina a si e justamente por aí determina seu agir e seu mundo: estes dois são ela mesma, pois exterior à Vontade não há nada. Só assim ela é verdadeiramente autônoma (W I, § 53, p. 355).

O engano sobre a liberdade empírica da vontade, sobre uma liberdade dos nossos atos individuais, de acordo com o autor, advém da posição do intelecto com relação à vontade. $\mathrm{O}$ intelecto experimenta as decisões da vontade somente a posteriori e de maneira

4 O texto em questão foi escrito para concorrer ao concurso organizado pela Sociedade Real de Ciências da Noruega, em 1839. Tendo sido premiado, foi, juntamente com o ensaio Sobre o fundamento da moral, publicado em 1840 sob o título de Os dois problemas fundamentais da ética.

5 Esse é, justamente, o tema que Schopenhauer desenvolverá, com maiores detalhes, no capítulo II dos Aforismos para a sabedoria de vida (1851), ao falar sobre o que alguém é, pois, como afirma, não há, para o sujeito humano, um consolo mais eficaz do que a completa certeza de uma necessidade inexorável. 
empírica. Assim, no momento em que uma escolha se faz presente, ele (intelecto) não tem dados suficientes para saber como a vontade decidirá, já que o caráter inteligível, que faz com que a decisão diante dos motivos dados seja necessária, não se mostra acessível ao seu conhecimento (do intelecto). Conhece-se apenas o caráter empírico, de modo sucessivo e por meio de atos isolados. Do mesmo modo, continua Schopenhauer, pode-se afirmar que a decisão da vontade é indeterminada apenas para o espectador, ou seja, o próprio intelecto ou o sujeito do conhecimento, já que, em contrapartida - para si mesma e objetivamente - a decisão é necessariamente determinada diante de cada escolha dada. Todavia, tal decisão só aparece para a consciência por meio da deliberação seguinte. Desse modo:

O intelecto nada pode fazer senão clarear a natureza dos motivos em todos os seus aspectos, porém sem ter condições de ele mesmo determinar a vontade, pois esta lhe é completamente inacessível, sim, até mesmo, como vimos, insondável (W I, § 55, p. 377).

Logo, conforme comenta Gabilondo ${ }^{6}$, Schopenhauer considera ignorante e brutal falar de uma liberdade nas ações individuais do homem, falar de um liberum arbitrium indifferentiae. O indivíduo, determinado que é em seus atos pela lei da motivação, é apenas o fenômeno. E sua índole está, assim, impressa em uma mesma medida em todos os seus atos que, em si, expressam seu caráter inteligível que, por sua vez, determina seu caráter empírico ${ }^{7}$.

Se o ato humano é o espelho da Vontade, pode-se dizer que o corpo está aí totalmente implicado, uma vez que é ele (corpo) que executa, materializa a Vontade de vida. Logo, o corpo também é um espelho da Vontade. Esse fato pode ser observado por meio do papel que o corpo ocupa no exercício seja da contemplação estética ou do fenômeno da compaixão: vê-se transparecer pelo corpo de um indivíduo seu assombro ou estupefação diante de uma bela tela, ao mesmo tempo em que as ações efetivas de auxílio aos semelhantes traduzem, via experiência da compaixão, a certeza da existência de uma Vontade inexorável, da qual todos fazem parte. Schopenhauer fornece incontáveis exemplos disso por meio dos modelos das vidas dos santos e dos ascetas.

A doutrina do estatuto primário e originário da Vontade distancia Schopenhauer da tradição espiritualista e intelectualista, que predominou na filosofia ocidental e levou à valorização do sujeito encarnado, uma vez que cada ser humano é o que é mediante sua vontade, e seu caráter é originário, já que querer é a base de seu ser; por meio do conhecimento, o homem apreende, através da experiência, o quê ele é, ou seja, seu caráter. Ora, se é dessa maneira, a conduta humana está, segundo Schopenhauer, determinada de modo fixo desde o nascimento, permanecendo a mesma até o final da vida e o que alguém quer não se modifica por uma ação exterior, pela via do conhecimento. Afinal, conforme Sêneca, velle non discitur (a virtude não pode ser ensinada). Por outro lado, o conhecimento é muito importante no tocante à eficácia dos motivos, uma vez que é por meio dele que o homem entende o sentido de seu agir. Conforme Schopenhauer:

Para que a proporção existente num dado homem entre egoísmo e compaixão possa entrar em cena, não é suficiente que possua riqueza e veja a miséria alheia: também tem de saber o que é permitido fazer com a riqueza, tanto para si quanto para os outros; ademais não apenas tem de ter sido apresentado ao sofrimento alheio, mas também tem de ter experimentado o que é o sofrimento, bem como o prazer (W I, § 55, p. 382).

Está indicado aí, de forma clara, como o filósofo ressalta o papel da razão e da experiência na ação ética. É nessa medida que se pode sustentar que o corpo está implicado na ética desde sempre, posto que é o palco onde tais ações são encenadas. É interessante 
notar essa participação imediata do corpo nos fenômenos éticos por meio do modo como os corpos daqueles tomados pela compaixão, ou pelo ódio, em contrapartida, se portam: naquele sujeito que se compadece com o sofrimento do outro, se identificando com ele e fazendo com que o motivo daquele que sofre seja o próprio motivador de suas ações, vêse uma harmonia entre o que alguém é (Vontade) e o que esse alguém faz. Essa harmonia é testemunhada através do corpo e do espírito, na alegria que é sentida ao se ajudar o outro. Por outro lado, também naquele que semeia o ódio e está tomado pelo egoísmo, isto transparece por meio da má disposição de caráter e da rigidez corporal. Na verdade, enquanto expressão imediata da Vontade, o corpo participa de todos os seus modos de aparição. É o sujeito quem sofre, por meio do seu corpo.

A prova da influência do conhecimento sobre o agir é dada pelo arrependimento. De acordo com Schopenhauer, o arrependimento não se deve ao fato de a Vontade ter mudado, o que é impossível, mas sim ao fato de o conhecimento ter sido modificado. Não se arrepende do que se quer, mas sim do que se faz. Novamente, o corpo se coloca aí, participante do processo ético também com relação ao arrependimento. Isso se confirma por meio das chamadas "dores morais", que afetam diretamente o corpo ${ }^{8}$. Schopenhauer ressalta, inclusive, que a capacidade de arrependimento diferencia, sobremaneira, o homem dos animais, cujo sofrimento é sempre motivado por uma representação intuitiva. O homem, ao contrário, tem como causa de seus sofrimentos os pensamentos abstratos, que afetam inteiramente o corpo:

\begin{abstract}
São estes [os pensamentos abstratos] que amiúde nos são insuportáveis, criam tormentos, em comparação com os quais o sofrimento do mundo animal é bastante pequeno; [...] eis por que nas maiores dores espirituais a pessoa arranca os cabelos, golpeia-se no peito, arranha o rosto, atira-se ao chão: tudo sendo propriamente apenas meios violentos de distração em face de um pensamento de fato insuportável. [...] De maneira semelhante, preocupações e paixões, portanto o jogo do pensamento, abalam o corpo muito mais frequente e intensamente que deficiências físicas (W I, § 55, p. 387).
\end{abstract}

Assim, é necessário um trabalho enorme do sujeito, por meio do que o filósofo denomina de decisão eletiva, ou simplesmente deliberação, para que o sujeito consiga ter clareza dos motivos que o levam a agir, pois apenas essa sua capacidade deliberativa é, segundo Schopenhauer, uma indicação clara de seu caráter, para si mesmo e para os outros. A decisão eletiva não deve ser entendida como liberdade do querer individual, mas é necessário que o homem deixe de lado o conhecimento, submetido ao princípio de razão e referente às coisas isoladas, e, por meio do conhecimento das Ideias, olhe através do principium individuationis. Apenas assim pode-se falar, de fato, em liberdade da Vontade. Contudo, tal decisão só é certa devido ao ato, pois a ação é a demonstração das leis inteligíveis de sua conduta, o fruto de seu querer mais íntimo,

E é como uma letra na palavra que exprime seu caráter empírico, o qual é apenas a manifestação temporal de seu caráter inteligível. Por isso, numa mente sadia, somente atos pesam na consciência moral, não desejos nem pensamentos. Pois apenas os nossos atos são o espelho de nossa vontade. (W I, § 55, p. 388).

Parece legítimo interpretar essa passagem como indicativa da participação efetiva do corpo no fenômeno ético, ou seja, nas ações morais do homem, já que é por meio do corpo que o caráter inteligível se afirma, tornando-se empírico nas ações de cada sujeito humano. Nada mais lógico, uma vez que o corpo é a objetivação mais imediata da Vontade no mundo.

8 Os aspectos que relacionam o corpo com a dor, em uma perspectiva psicanalítica, podem ser observados em MENDONÇA. As incidências da repetição no corpo, pela via da dor. Dissertação de Mestrado. Psicologia: UFMG, 2006. 


\section{O corpo na Afirmação e na Negação da Vontade de vida}

Preparando o caminho para desenvolver um dos aspectos mais importantes de seu pensamento ético - a auto abnegação da Vontade - Schopenhauer desenvolve a tese segundo a qual toda a vida é sofrimento. A vida é sofrimento porque a Vontade não cessa de se afirmar. A liberdade e a onipotência da Vontade se exteriorizam em todo o mundo visível como seu fenômeno. Contudo, conforme o filósofo, no ponto mais alto de sua clarividência e autoconsciência, a Vontade tem dois caminhos a seguir: continuar querendo o que queria antes, e o conhecimento aí não passa de um motivo, ou, ao contrário, tal conhecimento se lhe torna um quietivo, que suprime e silencia o querer. Tem-se, pois, a afirmação ou a negação da Vontade de vida. O autor afirma que o caminho para se entender tudo isso foi facilitado pelas considerações acerca da liberdade, da necessidade e do caráter.

De acordo com as suas considerações metafísicas, o filósofo entende que a Vontade carece de um fim e um objetivo últimos, ou seja, não há um sentido inteligível para o impulso perene da Vontade que se encontra sempre em movimento, pois o esforço é sua própria essência. Observa-se isso desde o mais simples dos fenômenos naturais, a gravidade, até a sua manifestação mais elevada na luz plena da consciência. Assim, sustenta Schopenhauer, "nomeamos SOFRIMENTO a sua travação por um obstáculo, posto entre ela e o seu fim passageiro; ao contrário, nomeamos SATISFAÇÃO, bem-estar, felicidade, o alcançamento do fim” (W I, § 56, p. 399, grifos do tradutor). Na medida em que o fenômeno da Vontade se aperfeiçoa, o sofrimento se torna mais manifesto. O corpo é testemunha direta disso, já que não há corpo sem esforço ou apetite, isto é, vê-se o corpo sempre querendo algo, ansiando por alguma satisfação, buscando a sua conservação na vida e abocanhando a sua parte na luta generalizada por sua parte da matéria. Porém, quando a Vontade vai se objetivando, a consciência se eleva e o tormento aumenta, alcançando seu ápice no homem justamente porque nele o querer viver toma consciência de si mesmo.

Nesse sentido, a existência humana é o destino secreto e essencial da Vontade e a vida do corpo não passa de um morrer ininterruptamente evitado, uma morte adiada, já que a base de todo o querer é sempre a carência e a necessidade, enfim, um sofrimento ao qual o homem está destinado desde sempre. Logo, a vida oscila entre a dor e o tédio, componentes básicos de todo viver, sendo o corpo o palco para as diversas manifestações de sofrimento:

O esforço contínuo que constitui a essência de cada fenômeno da Vontade adquire nos graus mais elevados de objetivação dela seu primeiro e mais universal fundamento, pois, aqui, a Vontade aparece num corpo vivo com o seu mandamento férreo de alimentação. $O$ que dá força a este mandamento é justamente que o corpo é apenas a Vontade de vida mesma, objetivada. O homem, como objetivação perfeita da Vontade, é, em conformidade com o dito, o mais necessitado de todos os seres. Ele é querer concreto e necessidade absoluta, é uma concretização de milhares de necessidades (W I, § 57, p. 402).

O sofrimento é inevitável, posto que faz parte do querer viver a todo custo. E, por conseguinte, o desejo é, por natureza, dor, mudando constantemente de figura, manifestando-se sob diferentes aspectos - impulso sexual, amor apaixonado, ciúme, inveja, ódio, angústia, ambição, avareza, doença. Se a vida é sofrimento, por outro lado, a satisfação plena é impossível. A consequência disso é, segundo Schopenhauer, uma "certa disposição melancólica”, por meio da qual alguém pode desdenhar os sofrimentos ou as pequenas alegrias. Tal disposição é um fenômeno mais digno, de acordo com o filósofo, e preferível à correria frenética por novas formas de ilusão.

A pós sustentar que a vida é sofrimento, Schopenhauer define o conceito de afirmação da Vontade. Vê-se reforçada aí, por meio dessa definição, a relação intrínseca do corpo com a vontade. De fato, é a partir das questões éticas, notadamente as relacionadas aos 
fenômenos de afirmação da Vontade de vida, que o papel do corpo se faz mais presente na filosofia do autor. Conforme suas próprias palavras:
A AFIRMAÇÃO DA VONTADE é o constante querer mesmo, não perturbado por conhecimento algum, tal qual preenche a vida do homem em geral. Ora, como o corpo do homem é já a objetidade da Vontade como ela aparece neste grau e neste indivíduo, segue-se que o querer individual, a desenvolver-se no tempo, é, por assim dizer, a paráfrase do corpo, a elucidação do sentido referente ao todo e às partes: é um outro modo de exposição da mesma coisa em si cujo fenômeno o corpo já é. Eis por que, em vez de afirmação da Vontade, podemos também dizer afirmação do corpo (W I, $\S 60$, p. 420 , grifos do tradutor).

O que significa dizer que o querer individual, ou a vontade fenomenicamente manifestada, é uma paráfrase do corpo? Schopenhauer destaca, por meio dessa afirmativa, o caráter de identidade do corpo com a Vontade, ou o sentido mesmo do corpo, que é expressar a Vontade em todos os aspectos possíveis. Logo, a essência do homem - a Vontade - inclui o corpo como testemunha de sua afirmação no mundo da vida. Isto torna o corpo, consequentemente, o objeto mais imediato de manifestação possível da Vontade. Ela toma o objeto corpo como o lugar onde se mostra de maneira mais efetiva, seja pela satisfação das necessidades fisiológicas desse corpo, seja pelos motivos que regem o querer individual, mas, principalmente, a Vontade dá a ver por meio do corpo algo do indizível do sofrimento humano, como acaba-se de analisar. Nesse sentido, a conexão do corpo com a Vontade torna o homem um sujeito encarnado, que padece, por meio de diversas manifestações corporais (sofrimentos de ordem psíquica e física), dos efeitos da sua relação imediata com a Vontade?.

A afirmação da Vontade, como dito, consiste no impulso cego do querer viver e no conflito daí decorrente de apropriação, por parte de cada indivíduo, de uma parte da quantidade constante da matéria. A vida é uma luta pela conservação de si de cada indivíduo, uma luta que se traduz na satisfação das necessidades do corpo, mantendo-o saudável, mas também se traduz na continuidade geracional, ou seja, na propagação da espécie. Nessa medida, a maioria das pessoas passa a vida tentando satisfazer suas necessidades e sua consciência, que está, desde o momento de seu nascimento, em constante relação com a vontade, trabalha para chegar ao objetivo de seu querer. A conservação do corpo é um grau menor de afirmação da Vontade quando comparada à satisfação do impulso sexual que, de acordo com o autor, ultrapassa a afirmação da própria existência, afirmando a vida por um tempo além da morte do indivíduo. Isto permite a Schopenhauer afirmar que a veemência do impulso sexual é a mais decidida expressão da Vontade de vida. Tal aspecto se confirma no fato de o impulso sexual ser o fim último, o objetivo supremo da vida de um sujeito. Assim, depois de assegurada a auto conservação, o homem se preocupa apenas com a propagação da espécie. Daí o filósofo dizer, também, que os genitais são o foco da Vontade, como princípio conservador vital em que somente a Vontade participa, excluindo-se aí qualquer participação do cérebro, como representante do conhecimento.

Todos esses aspectos são relativos aos fenômenos de afirmação da Vontade, que Schopenhauer define como sendo o constante querer viver que não pode ser perturbado por nenhum conhecimento e que ocupa, em geral, toda a vida de um homem. Contudo,

\footnotetext{
Uma discussão contemporânea acerca da ética, que inclui questões relativas ao corpo, e que articula a filosofia schopenhaueriana com a psicanálise, pode ser encontrada em: MARTINS, E. Freud e Schopenhauer: os limites de um diálogo sobre a moral. São Carlos: Centro de Educação em Ciências Humanas. Dissertação de Mestrado em Filosofia. UFSCar, 2006; ROCHA, Z. A experiência psicanalítica: seus desafios e vicissitudes, hoje e amanhã. Ágora, Rio de Janeiro, vol. XI, n.1 Jan/Jun, 101-116, 2008; SORIA, A. C. S. Freud e o porto da filosofia de Schopenhauer. In: FONSECA, E.R.; MATTOS, F.C.; RAMOS, F.C.; HULSHOF, M.; DEBONA, V. (Org.) Dogmatismo e antidogmatismo: filosofia crítica, vontade e liberdade. Uma homenagem a Maria Lúcia Mello e Oliveira Cacciola. 1ª ed. Curitiba: Editora da UFPR, v.0, p.311-323, 2015.
} 
vem daí o fato de a vida ser sofrimento, já que o mundo, como fenômeno da Vontade, é como é. A Vontade, por sua vez, afirma-se a si mesma neste mundo incessantemente, como se torna manifesto no comportamento egoísta. Nele se concentra toda a luta, e a partir daí pode-se pensar na instauração do conflito interno da Vontade consigo mesma. A origem do egoísmo está no princípio de individuação, ou seja, o tempo e o espaço, como o que possibilita as diversas manifestações da Vontade:

Todo indivíduo que conhece é e encontra a si mesmo como a Vontade de vida em sua totalidade, como o em-si do mundo, portanto, como a condição complementar do mundo como representação, consequentemente como um microcosmo equivalente ao macrocosmo (W I, § 61, p. 426).

Cada indivíduo toma a si mesmo como o centro do universo, alçando ao primeiro plano sua própria existência e seu bem-estar e, desse ponto de vista, é capaz até de aniquilar o mundo para conservar um pouco mais do próprio si-mesmo. Aí está a mentalidade característica do egoísmo, por meio do qual o conflito interno da Vontade consigo mesma torna-se evidente.

Tais considerações sobre o egoísmo preparam o caminho para Schopenhauer desenvolver sua teoria do direito. Esse percurso permitirá que ele discorra sobre aspectos relativos ao conflito interno da Vontade consigo mesma, com pontuações sobre a vingança e a maldade, por exemplo. Somente depois disso, as considerações sobre a negação da Vontade entram em cena. Interessa observar aqui em que medida tais aspectos, acerca de seu pensamento sobre a justiça e a injustiça, afetam o corpo. Logo, a análise dessa parte do pensamento do autor incide somente sobre estes pontos específicos.

Schopenhauer inicia o parágrafo 62 do Livro IV de O mundo, dedicado à doutrina do direito, reafirmando a participação do corpo no processo ético. De acordo com o exposto por ele, a mera afirmação do próprio corpo é tida como a primeira e mais simples afirmação da Vontade de vida, uma vez que tal afirmação se manifesta imediatamente como conservação do corpo, o que acontece, por exemplo, pela via da satisfação do impulso sexual. Segue daí o fato de que a renúncia voluntária à satisfação desse impulso é uma negação da Vontade de vida, por se tratar de uma autossupressão voluntária do querer, por meio da entrada em cena de um conhecimento que age como um quietivo para a Vontade. Nesse sentido:

\begin{abstract}
A negação do próprio corpo já se expõe como uma contradição da Vontade com seu fenômeno, pois, embora também aqui o corpo objetive, nos genitais, a Vontade de propagação, esta, no entanto, não é desejada. Exatamente porque essa renúncia é negação ou supressão da Vontade de vida, ela é uma auto superação difícil e dolorida (W I, § 62, p. 428).
\end{abstract}

Schopenhauer introduz, então, o conceito de injustiça a partir da articulação da afirmação do corpo com a negação da Vontade de vida. De acordo com esse ponto de vista, há injustiça na medida em que a vontade de um indivíduo invade os limites da afirmação da vontade alheia, por meio da destruição ou ferimento do corpo do outro ou, ainda, ao impelir as forças alheias a servir sua vontade em lugar de servir à vontade que se dá a ver no corpo do outro. Portanto, "da vontade que aparece como corpo alheio, subtrai as forças desse corpo e assim aumenta a força a serviço de SUA vontade para além daquela do seu corpo" (W I, § 62, p. 429, grifos do tradutor), afirmando sua vontade mediante a negação da vontade presente no corpo do outro indivíduo.

Quem sofre a injustiça sente a invasão na esfera de afirmação do próprio corpo, via negação deste por um indivíduo estranho, como uma dor imediata, espiritual, completamente separada e diferente do sofrimento físico infligido pelo ato, ou do pesar provocado pela perda (W I, § 62, p. 429).

Por outro lado, quem pratica a injustiça tem acesso imediato ao conhecimento de que é, em si, manifestação da mesma Vontade que se apresenta no corpo alheio: 


\begin{abstract}
Afirmando-se com tanta veemência num único fenômeno que, ao transgredir os limites do próprio corpo e de suas forças, torna-se negação exatamente dessa Vontade no outro fenômeno e, por conseguinte, tomado como Vontade em si, entra em conflito consigo mesmo precisamente por meio dessa veemência, cravando os dentes na própria carne. [...] Esse conhecimento apresenta-se instantaneamente não in abstrato, mas como um sentimento obscuro, o qual se denomina mordida de consciência (W I, § 62, p. 429).
\end{abstract}

Está posto aí, por meio da prática da injustiça, o conflito da Vontade consigo mesma a partir do qual ela (Vontade) decidirá ou continuar se afirmando ou negar-se a si mesma.

Segundo Schopenhauer, são exercícios da injustiça a violência e a astúcia, assim como a mentira, uma vez que em tais atos observamos o objetivo de extensão do domínio da vontade de um indivíduo sobre os outros, afirmando-se, dessa maneira, a vontade pessoal por meio da negação da vontade alheia. O conceito de injustiça é originário e positivo, ao passo que o de justiça é derivado e negativo. Vemos, aqui, o filósofo deduzir claramente o conceito de injustiça dos de egoísmo e maldade, tal como ocorre em Sobre o fundamento da moral. Neste sentido, a justiça é a negação da injustiça, manifestando-se por meio de toda ação que não seja negação da vontade do outro em favor da afirmação da vontade própria. Desse modo, quando um indivíduo afirma sua vontade em detrimento da vontade de outro indivíduo, negando essa vontade, resta àquele que sofreu o ato injusto, como defesa diante de tal invasão, a negação daquela negação, portanto, a ele resta a afirmação da Vontade "que aparece essencial e originalmente em meu corpo e implicite se expressa por meio do simples fenômeno desse corpo” (W I, § 62, p. 435).

De acordo com o autor, injustiça e justiça devem ser consideradas como simples determinações morais, ou seja, relacionadas à conduta humana e à significação dessa conduta em si. Tal significação, por sua vez, é anunciada imediatamente na consciência de cada um. Na prática da injustiça, isto ocorre pelo fato de esta ser acompanhada por uma dor interior, o remorso e, quanto àquele que sofre a injustiça, vemos o significado moral dessa ação por meio da consciência que tal indivíduo tem da negação de sua vontade. Schopenhauer sustenta que o ato de sofrer injustiça é uma ocorrência na experiência, e por isso aí se manifesta de forma mais evidente o fenômeno do conflito da Vontade de vida consigo mesma, uma vez que tal conflito se origina do egoísmo e da pluralidade de indivíduos, condicionados que são pelo princípio de individuação. Ora, o corpo é testemunha dos atos de injustiça e de justiça, já que a experiência de tais ações é uma experiência corporal. O agir humano é, pois, a exteriorização da Vontade e somente o agir é considerado pela moral schopenhaueriana. Consequentemente, a ética se ocupa do corpo à medida que é por meio dele que as ações éticas podem se efetivar, como sustenta Schopenhauer ao descrever os limites da afirmação e da negação da Vontade de vida no corpo próprio e no corpo do outro. Logo, a questão ética, para o autor, não pode prescindir do corpo.

Após esse percurso de investigação das analogias do corpo com relação aos aspectos referentes à afirmação da Vontade de vida, pode-se apresentar de maneira mais clara o conceito de negação da Vontade, que é tema dos últimos parágrafos do Livro IV de $\mathrm{O}$ mundo como vontade e como representação e do qual o corpo também participa.

Para Schopenhauer, há justiça quando se consegue ver através do principium individuationis, ao passo que o indivíduo injusto está inteiramente absorvido por esse princípio. Logo, a ultrapassagem do princípio de individuação é um caminho necessário no processo de autoconhecimento da Vontade e, consequentemente, em sua decisão de negarse, ou não. O primeiro caso pode ocorrer em graus mais elevados do que se dá na justiça, impulsionando, por exemplo, os atos de benevolência e caridade. O autor ressalta que isso pode acontecer independentemente de quão enérgica é a vontade em si mesma, manifestada em um indivíduo, pois, nele, o conhecimento é capaz de conduzi-lo à equanimidade. 
A visão, através do princípio de individuação, é a única que suprime a diferença entre os indivíduos, tornando possíveis o amor desinteressado e a compaixão pelo outro. Nessa medida, o indivíduo percebe que tudo lhe é próximo; todos os tormentos que vê no mundo, todas as dores existentes e o sofrimento alheio tocam-lhe o espírito como se fossem seus. Conhece, assim, o todo, alcança o seu ser e percebe o mundo num perecimento constante, num esforço vão e em um íntimo conflito. Ora, como seria possível, a partir de tal conhecimento do mundo, continuar afirmando a vida por meio de constantes atos da Vontade? Conforme observa o filósofo:

\begin{abstract}
Se, portanto, quem ainda se encontra envolvido no principium individuationis conhece apenas coisas isoladas e sua relação com a própria pessoa, coisas que renovadamente se tornam MOTIVOS para seu querer, ao contrário, aquele conhecimento do todo e da essência das coisas torna-se QUIETIVO de toda e qualquer volição. Doravante a Vontade efetua uma viragem diante da vida: fica terrificada em face dos prazeres nos quais reconhece a afirmação desta. O homem, então, atinge o estado de voluntária renúncia, resignação, verdadeira serenidade e completa destituição de Vontade (W I, $\S 68$, p. 481-82, grifos do tradutor).
\end{abstract}

Quando o indivíduo, capaz de ver através do princípio de individuação, não tem mais nenhum consolo:

Sua Vontade se vira; ela não mais afirma a própria essência espelhada no fenômeno, mas a nega. O acontecimento, pelo qual isso se anuncia, é a transição da virtude à ASCESE (W I, § 68, p. 482, grifos do tradutor).

A negação da Vontade passa necessariamente pela contenção do querer viver, que se manifesta antes de tudo no corpo, como testemunha, por exemplo, a decisão racional e voluntária de não mais satisfazer o impulso sexual.

O filósofo explica essa viragem da Vontade dizendo que não é suficiente apenas amar aos outros como a si mesmo, pois dela nasce uma aversão pela Vontade de vida como sendo o cerne do mundo repleto de penúrias. O indivíduo renega, então, essa essência mesma que nele aparece em seu corpo. Além de desmentir, com seus atos, os fenômenos dessa mesma Vontade, cessando de querer algo e evitando atrelar sua vontade a alguma coisa:

Seu corpo saudável e forte exprime o impulso sexual pelos genitais; porém agora nega a Vontade e desmente o corpo: não quer satisfação sexual alguma, sob nenhuma condição. Voluntária e completa castidade é o primeiro passo na ascese ou negação da Vontade de vida. A castidade, assim, nega a firmação da Vontade que vai além da vida individual, e anuncia que, com a vida deste corpo, também a Vontade, da qual o corpo é fenômeno, se suprime (W I, § 68, p. 483).

Schopenhauer sustenta, ainda, que negar a Vontade significa ir intencionalmente contra os desejos, como ocorre no caso da pobreza voluntária. Quem vive a pobreza como um fim em si mesmo mortifica continuamente a Vontade, mas, ainda assim, sente - por meio do corpo, fenômeno concreto da Vontade - uma disposição natural a todo tipo de volição, ainda que a refreie na firmeza de seu propósito. $\mathrm{O}$ indivíduo que nega a Vontade mortifica, inclusive, sua objetidade, ou seja, o corpo, alimentando-o modicamente com o objetivo de evitar que floresça e se afirme e, desse modo, impede que ele (corpo) anime a Vontade, da qual é espelho e expressão. Portanto, a prática do jejum, da castidade, assim como a autopunição e o autoflagelo são meios de anular e mortificar a Vontade. Esse esforço de mortificação da Vontade pode acabar por levar à morte do corpo, desde que se tenha em mente que o corpo, apenas um fenômeno da Vontade, perde todo o seu significado a partir do momento em que há a supressão da Vontade de vida. De acordo com Schopenhauer, a morte do corpo nestas circunstâncias não é vista como amarga, mas, ao contrário, é muito bem acolhida. 
Barbosa $^{10}$ refere-se à participação do corpo no processo de negação da Vontade, concordando com o ponto de vista que tem sido enfatizado no presente exame, ou seja, o corpo está intimamente envolvido não somente nos aspectos relativos à afirmação da Vontade de vida, mas, sobretudo, em sua negação. Essa autora salienta que apenas o homem é capaz de negar-se, apenas o homem como fenômeno da Vontade ou, melhor dizendo, o homem encarnado. Para ela o corpo deve estar sempre pressuposto, pois, "arrancar a vida do corpo não leva ninguém à salvação. Somente quem vive e, durante a vida, mortifica a Vontade, pode livrar-se do mundo do sofrimento"11.

Por sua vez, Palao ${ }^{12}$, ao discutir diversos aspectos acerca da teoria da negação da Vontade de vida, também alude à participação do corpo como um ponto importante neste processo. Segundo seu ponto de vista, a ética schopenhaueriana é paradoxal: uma vez que o mundo é a autocontradição da Vontade, sua negação pode ser entendida como sendo um retorno à sua identidade mesma, um repouso lógico, ou seja, tal negação não passa da negação de uma contradição. Schopenhauer é incisivo ao afirmar que o que se pode vislumbrar por trás da compaixão e da caridade é o cuidado com o outro que, em essência, é idêntico a nós mesmos, que se reconhece em sua condição comum de sujeito encarnado: "A caridade e a compaixão são semelhantes aos cuidados com o próprio corpo, à atenção com as próprias feridas" ${ }^{13}$. Nesse sentido, o dito védico Tat twam asi (Tu és isto) deve ser entendido a partir da lógica da identidade. Schopenhauer exemplifica esse processo de negação do corpo por meio dos relatos das vidas dos santos e dos ascetas, ou seja, daqueles que, por meio de enorme esforço ascético, neutralizaram o impulso cego de seu querer viver.

\section{O corpo e a ética a partir de Parerga e paralipomena}

De acordo com Caldeira Ramos ${ }^{14}$, a obra Parerga e paralipomena: pequenos escritos filosóficos (1851), que consiste em um conjunto de ensaios e aforismos, tem a função de ilustrar e complementar a filosofia de Schopenhauer tal como exposta em $O$ mundo como vontade e como representação. Essa obra foi publicada em dois volumes e é a responsável pela fama que o filósofo obteve, principalmente entre os artistas, na segunda metade do século XIX. A presente análise incide brevemente sobre dois ensaios dessa vasta coletânea: "Sobre a ética" e "Aforismos para a sabedoria de vida" que, em português, foram publicados separadamente.

O ensaio "Sobre a ética" constitui o capítulo oito do segundo volume dos Parerga e expõe, de uma forma mais geral, a filosofia moral como um todo, procurando reiterar os pontos principais dessa parte do pensamento de Schopenhauer. Desse modo, aborda temas de uma teoria já consolidada, como o significado ético das ações humanas e a compaixão como sendo o fundamento do agir moral. Em alguns pontos do texto, vê-se Schopenhauer se referir ao homem como sendo um animal malvado por excelência, sem dignidade alguma. Salienta-se que o autor tenta traçar um perfil de homem caracterizado pela malignidade e o responsabiliza pelos males da vida dos indivíduos. Obviamente, na acepção schopenhaueriana, esse mal tem suas raízes na própria essência do homem, ou seja, na vontade:

O conceito de dignidade só pode ser aplicado de maneira irônica a um ser de vontade tão pecaminosa, de espírito tão limitado e de corpo tão vulnerável e frágil como o homem: Quid superbit homo? cujus conceptio culpa, Nasci poena, labor vita, necesse mori! (Sobre a ética, § 109, p. 40)15.

\footnotetext{
${ }_{10}$ Cf. BARBOSA. Schopenhauer e o corpo. In: La Salle, vol.8, n.1, p. 31-54, outubro de 2003.

${ }^{11}$ BARBOSA. Schopenhauer e o corpo, p. 54.

${ }^{12}$ Cf. PALAO. La sabiduria budista del vacío. In: URDANIBIA. (Coord.) Los Antihegelianos: Kierkegaard Schopenhauer. Barcelona: Anthropos, 1990, p. 211-237.

${ }^{13}$ PALAO. La sabiduria budista del vacío, p. 221. Tradução livre.

${ }^{14}$ CALDEIRA RAMOS. Introdução. In: SCHOPENHAUER. Sobre a ética. São Paulo: Hedra, 2012.

${ }^{15}$ SCHOPENHAUER. Sobre a ética, p. 40. "Do que se orgulha o homem? Sua concepção é uma culpa, / o nascimento, um castigo, a vida, uma labuta, a morte, uma necessidade!" (versos latinos de Schopenhauer, segundo nota do tradutor).
} 
Ainda:

O homem é no fundo um animal selvagem, terrível. Nós o conhecemos meramente no estado subjugado e domesticado que se denomina civilização: por isso nos apavoram as eventuais irrupções de sua natureza. Mas onde e quando a fechadura e a cadeia da ordem legal se rompem e a anarquia se instaura, então se mostra o que ele é (Sobre a ética, § 114, p. 52).

O animal feroz que é o homem fica sempre à espera de uma ocasião para prejudicar o outro, para aniquilá-lo. Para ser domesticado e mantido sob certos limites, necessita da ocupação integral do conhecimento.

De qualquer modo, denominemo-lo mal radical, o que ao menos servirá àqueles que se contentam com uma palavra no lugar de uma explicação. Eu, porém, afirmo: é a vontade de viver, cada vez mais e mais amargurada pelo constante sofrimento da existência, que procura aliviar sua própria dor causando a dos outros (Sobre a ética, § 114, p. 56).

Tais observações de Schopenhauer, que ressaltam a natureza maldosa inerente ao homem, podem ajudar a pensar o mal-estar contemporâneo, que se dá a ver por meio das figuras da violência e da indiferença com relação ao sofrimento alheio e que adotam o corpo como um palco muito particular de suas manifestações ${ }^{16}$.

"Aforismos para a sabedoria de vida" pode ser interpretado como sendo uma saída otimista em meio ao dito pessimismo metafísico que se instaura na filosofia schopenhaueriana a partir do Livro IV de $\mathrm{O}$ mundo ${ }^{17}$. Ao longo desse ensaio, o autor faz adendos à base metafisica de sua ética da compaixão, principalmente nos capítulos II, III e IV, que versam sobre o que alguém é, tem e representa e sobre como tais características influenciam, ou não, a felicidade humana. Schopenhauer sustenta que a capacidade de felicidade está naquilo que se é, ou seja, na personalidade do indivíduo. Propriedades, posses e o modo como os outros se representam ficam em segundo plano quando se trata das influências sobre a vida feliz. O que alguém é diz respeito ao modo como a natureza operou sobre os homens, ao modo como se experimenta o mundo imediatamente, por meio das próprias representações, sentimentos e movimentos da vontade.

Ora, não é novidade ver o filósofo enfatizar a importância da representação que se tem do mundo para a concepção do próprio mundo. Logo, acompanha-lo no desenvolvimento desses capítulos é outra forma de vê-lo desenvolvendo a ideia de que o mundo é minha representação. A conquista da felicidade depende basicamente do caráter, pois cada um "está preso à própria consciência como à própria pele, e vive imediatamente apenas nela. Por conseguinte, o que vem de fora é de pouca importância” (A, cap. I, p. 5). Nesse sentido, a máxima operari sequitur esse se dá a ver em afirmações precisas: a metade subjetiva do presente e da realidade somos nós mesmos e ela é, em essência, inalterável; a vida de cada homem comporta sempre o mesmo caráter, que varia sobre um mesmo tema; enfim, não é possível escapar à própria individualidade, que determina de antemão o grau possível da felicidade de cada um.

Como pensar o papel do corpo na ética, a partir do preceito operari sequitur esse? Desenvolvendo a ideia de que o agir segue o ser. Mas o que é o ser em Schopenhauer? O ser é a Vontade, mas será que o corpo pode ser compreendido como outro nome para a Vontade, já que o corpo materializa a vontade, dando forma a ela, tornando-a palpável? Ou o corpo está do lado do operari? Nesse sentido, o corpo é ação, manifestação mais imediata da essência do mundo e da vida que é a Vontade. Ambas as alternativas são possíveis: o corpo é, concomitantemente, manifestação e experiência da Vontade. Ao se tomar como ponto de partida o mundo como

\footnotetext{
16 Uma discussão sobre a questão do mal-estar contemporâneo, que inlui a articulação do corpo com a ética na filosofia e na psicanálise pode ser encontrada em: MENDONÇA, A dimensão ética do corpo nos pensamentos de Schopenhauer e de Freud. Tese de Doutorado. Filosofia: UFMG, 2015. Pesquisa financiada pela CAPES.

17 Cf. BARBOZA. Prefácio, p. IX-XVIII. In: SCHOPENHAUER. Aforismos para a sabedoria de vida. São Paulo: Martins Fontes, 2006; DEBONA. Schopenhauer e as formas da razão: o teórico, o prático e o ético-místico, p. 58-62.
} 
representação, o corpo é a objetidade da Vontade, seu modo mais imediato de se manifestar no mundo, mas, ao contrário, ao se analisar o mundo na perspectiva da Vontade, o corpo é a própria Vontade, experienciada e vivida por meio dos próprios motivos que regem esse objeto desejante.

De acordo com os Aforismos, a condição de sujeitos encarnados é essencial para a felicidade, o que é confirmado em tudo, desde o mais elementar, a fome, até o mais elevado, a vida do gênio e do santo. A saúde tem um papel especial também, já que supera os bens exteriores. Logo, um temperamento calmo e jovial, fruto de uma boa saúde, ao lado de um entendimento lúcido e penetrante e de uma vontade moderada, que permita uma consciência boa, são atributos mais poderosos que qualquer posição ou riqueza. O que alguém é para si mesmo, o que acompanha o homem na solidão e não é possível ser dado ou retirado, é mais essencial do que tudo que se possa possuir. Isso se justifica quando se vê um caráter bom e brando sentindo-se satisfeito em condições adversas, ao passo que alguém invejoso e mau não se contenta com nada. Portanto, a felicidade depende do que se é, pois a personalidade é constante e ativa em todas as esferas da vida, tornando-se, por conta disso, um valor absoluto. Somente o tempo exerce aqui seu poder, mas o caráter moral permanece imune a ele.

Como procede em Sobre ofundamento da moral, Schopenhauer coloca a dor e o tédio como sendo os dois maiores inimigos da felicidade humana, sustentando que o homem inteligente aspirará sempre à ausência de dor, à serenidade, ao sossego e ao ócio, ou seja, à existência livre. Desse modo, ele dará prioridade a uma vida tranquila, já que quanto mais alguém tem em si mesmo menos necessita do mundo e dos outros.

Tal qual faz Aristóteles ${ }^{18}$, o autor defende a necessidade do ócio para o desenvolvimento interior e a consequente felicidade humana. Ao lado dele (ócio) e das qualidades físicas, o aspecto intelectual também tem forte influência na capacidade de ser feliz. Inicialmente, as virtudes intelectuais beneficiam a si próprio, ao passo que as virtudes morais contribuem para o bem-estar dos outros. Para ser feliz é preciso, pois, um excesso de intelecto que seja capaz de ultrapassar a medida exigida pela vontade, possibilitando o exercício de uma vida intelectual que ocupe a mente de forma indolor, contudo, vivaz e que, gradualmente, se torne o verdadeiro fim. Nosso filósofo defende, ainda, que um excedente real de força se faça presente, já que este capacitará o homem a uma ocupação estritamente espiritual, não dependente apenas do exercício da vontade.

A figura do gênio também ganha importância nesse aspecto de sua teorização, justamente por ser o que efetiva de maneira mais equilibrada a existência e a essência das coisas. A pessoa do gênio tem seu centro gravitacional em si própria, tendendo, pois, ao equilíbrio e à felicidade. Apenas para ele (gênio) a ocupação com seus pensamentos é uma necessidade, fazendo da solidão algo sempre bem-vindo. Consola-se com tudo, desde que se tenha a si mesmo. Há neles, então, como salienta Schopenhauer, um elemento isolante a mais, que os torna mais satisfeitos consigo próprios do que com os outros ${ }^{19}$. Contudo, àqueles indivíduos que não se enquadram na categoria dos gênios, resta mortificar a Vontade para tentar ser feliz, o que é algo bem raro.

Ao acompanhar as reflexões do filósofo, acerca da vida ética e da obtenção da felicidade, verifica-se que não se pode prescindir da articulação entre a ética da compaixão e a antropologia do homem como sujeito encarnado. A ética não reside em boas intenções e nem na busca de algum bem espiritual ou transcendente, mas existe concretamente nas ações efetivas dos indivíduos, que se dirigem aos outros indivíduos, percebidos antes de tudo, como corpos padecentes. Aqui se pode discernir uma viragem fundamental do pensamento filosófico. $\mathrm{Na}$ tradição ocidental, a tendência predominante consiste em escamotear o corpo humano em nome de uma visão metafísica otimista e presidida pela inteligibilidade do mundo: apesar da percepção do enorme sofrimento que há no mundo, é possível considerá-lo como superficial e

\footnotetext{
${ }_{18}$ Cf. ARISTÓTELES. Ética a Nicômaco, X, 7, 8 e 9. Trad.Antônio de Castro Caeiro. São Paulo: Atlas, 2009.

19 Para um exame mais aprofundado acerca do papel do gênio no pensamento de Schopenhauer, ver SOARES, D. Q. F. 2011.

O gênio e o santo na filosofia de Schopenhauer. Revista Voluntas: Estudos sobre Schopenhauer, vol. 2, no.1, pp.83-94.
} 
secundário, ao se focalizar na essência inteligível da realidade, que somente é acessível por meio do espírito ou da inteligência. Por isso, o sofrimento pode ser minimizado. Desse modo, Leibniz, como representante do grande racionalismo moderno, pôde propor, em sua "Teodicéia", a ideia de que se vive no melhor dos mundos possíveis. Essa é uma conclusão somente possível através de uma razão abstrata e desencarnada, capaz de se colocar para além da vida humana concreta. No entanto, se o "para além” se refere ao que se encontra além da razão e da inteligência espiritual, ou seja, a Vontade una e imperecível como fundo último da realidade, que é dada na representação, então não há como desconsiderar o corpo e o sofrimento humano. A simples dor de viver, que não pode ser resgatada por nenhuma visão moral do mundo, ganha o primeiro plano e obriga a uma dura crítica da superficialidade e da loucura da civilização.

\section{Referências}

ARISTÓTELES. Ética a Nicômaco. Trad. Antônio de Castro Caeiro. São Paulo: Atlas, 2009.

BARBOSA, Melissa. Schopenhauer e o corpo. La Salle, vol. 8, no. 1, p. 31-54, 2003.

DEBONA, Vilmar. Schopenhauer e as formas da razão: o teórico, o prático e o ético-místico. São Paulo: Annablume, 2010.

JANAWAY, Christopher. The Cambridge Companion to Schopenhauer. Cambridge: University Press, 1999.

MARTINS, Eduardo. "Freud e Schopenhauer: os limites de um diálogo sobre a moral”. São Carlos: Centro de Educação em Ciências Humanas. Dissertação de Mestrado em Filosofia. UFSCar, 2006.

MENDONÇA, Marinella Morgana. “As incidências da repetição no corpo, pela via da dor”. Belo Horizonte: Faculdade de Filosofia e Ciências Humanas. Dissertação de Mestrado em Psicologia. UFMG, 2006.

MENDONÇA, Marinella Morgana. "A dimensão ética do corpo nos pensamentos de Schopenhauer e de Freud". Belo Horizonte: Faculdade de Filosofia e Ciências Humanas. Tese de Doutorado em Filosofia. UFMG, 2015.

PALAO, Antonio. La sabiduria budista del vacío. In: URDANIBIA, Javier. (Coord.) Los Antihegelianos: Kierkgaard y Schopenhauer. Barcelona: Anthropos, 1990.

ROCHA, Zeferino. A experiência psicanalítica: seus desafios e vicissitudes, hoje e amanhã. Ágora, Rio de Janeiro, 2008, vol. XI, n.1 Jan/Jun, 101-116.

SCHOPENHAUER, Arthur. Sobre o fundamento da moral. Trad. Maria Lucia Cacciola. São Paulo: Martins Fontes, 2001.

SCHOPENHAUER, Arthur. O mundo como vontade e como representação. Tomo I. Trad., apresentação, notas e índices Jair Barboza. São Paulo: UNESP, 2005.

SCHOPENHAUER, Arthur. Aforismos para a sabedoria de vida. Trad. Jair Barboza. São Paulo: Martins Fontes, 2006.

SCHOPENHAUER, Arthur. Sobre la libertad de la voluntad. Trad. Ángel Gabilondo. Madrid: Alianza, 2007.

SCHOPENHAUER, Arthur. Sobre a ética. (Capítulos 8 - 15 de Parerga e Paralipomena de Arthur Schopenhauer). Organização e tradução Flamarion Caldeira Ramos. São Paulo: Hedra, 2012.

SOARES, Daniel Quaresma Figueira. O gênio e o santo na filosofia de Schopenhauer. Revista Voluntas: Estudos sobre Schopenhauer, vol. 2, no.1, pp.83-94, 2011.

SORIA, Ana Carolina Soliva. Freud e o porto da filosofia de Schopenhauer. In: FONSECA, E.R.; MATTOS, F.C.; RAMOS, F.C.; HULSHOF, M.; DEBONA, V. (Org.) Dogmatismo e antidogmatismo: filosofia crítica, vontade e liberdade. Uma homenagem a Maria Lúcia Mello e Oliveira Cacciola. 1a ed. Curitiba: Editora da UFPR, v.0, p.311-323, 2015. 